\title{
The final result of slope Optimization program at Grasberg surface mine in Papua, Indonesia
}

\author{
M Mahayasa Freeport-McMoran Inc., United States \\ E Widijanto PT Freeport Indonesia, Indonesia
}

AT Yuniar PT Freeport Indonesia, Indonesia

R Gautama PT Freeport Indonesia, Indonesia

\begin{abstract}
In order to maximize the pit value and achieve final pit design in a safe manner, the Grasberg surface mine initiated the slope optimization program in fourth quarter 2017; this program lasted 15 months before achieving the final pit. The optimization program focused on the Grasberg Intrusive Complex at radial sector $200^{\circ}-360^{\circ}$ with final Inter-ramp Slope Angle (ISA) up to $60^{\circ}$. By the end of 2018 , this program successfully had added 255 million pounds of copper and 660 kilo ounces of gold by opening extra width of the pushbacks and deepening the pit by two benches. Further mining of the Grasberg ore body will utilize block caving. The pit optimization had brought some of the block cave ore forward by a couple years and increased the value and life of the open pit. The pit steepening required intensive control and supervision to be successful. This paper outlines the slope optimization program at the end of the pit mining operations, requirements of the drill and blast improvement team, cutting-edge technology to provide actual wall condition for the quality control program, slope remediation and protection, realtime geotech monitoring program, and excavation control to manage geotechnical risks and maximize pit value.
\end{abstract}

\section{Introduction}

The dimensions of the Grasberg open pit mine, operated by PT Freeport Indonesia, is up to $3.5 \mathrm{~km}$ in diameter at 4,285 $\mathrm{m}$ above sea level, and the deposit continues $1.8 \mathrm{~km}$ deep, associated with volcanic rocks and quartz monzodiorite intrusions that form the Grasberg Igneous Complex (GIC). The aerial view of Grasberg on 2019 is shown on Figure 1.

The Grasberg open pit had experienced several times of slope optimization during the pit life. In 2002, Geotechnical group initiated the slope steepening program inside Grasberg ore body at PB5N at elevation 3625L to 3503L. It increased the bench face angle (BFA) from 63 degrees to 70 degrees and the inter-ramp slope angle (ISA) from 42 degrees to 49 degrees. Based on geotechnical group review, the inter-ramp slope stability was not an issue on the slope steepening at Grasberg open pit mine. It is more an issue on the safety of men and equipment because there will be an insufficient catch bench width probability to provide catchment for rockfall. Therefore, several pre-requisites were recommended to achieve catch bench width probability criteria especially in the drilling and blasting technique (Nicholas 2002). In 2003, Grasberg open pit experience major slide up to $235,000 \mathrm{~m}^{3}$ of material which give us valuable lesson learn in developing high wall slope, especially dealing with complex material type, high pore pressure wall, controlling drilling and blasting and mining sequence methodology (Schmelter \& Nicholas 2004). In 2006, the optimization program was applied on PB6S which implement pre-split holes in every pushback wall and excavation-blasting controlled methodology (Gautama \& Yuniar 2017). 


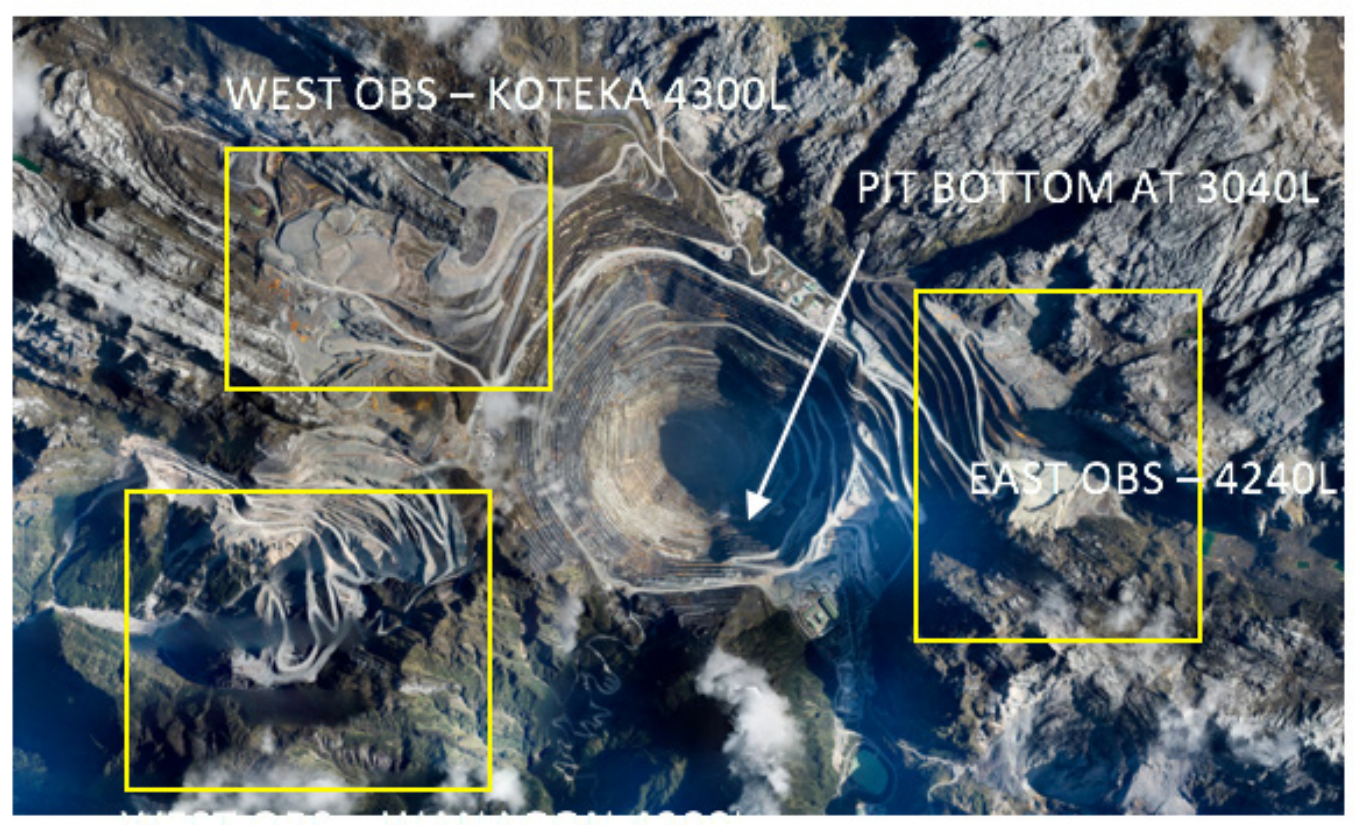

Figure 1 Aerial photograph of Grasberg open pit and its surrounding area (March 6, 2019)

For the period of 1990 to 2018, 4,800 million tons of material was mined, which consisted of 1,350 million tons of ore (average $1.07 \% \mathrm{Cu}$ and $1.29 \mathrm{~g} / \mathrm{t} \mathrm{Au}$ ) and 3,450 million tons of waste at a stripping ratio of 2.6. The ore was hauled to the crushers near the edge of the pit, and the waste material was hauled to overburden stockpiles. The production history of the Grasberg pit is shown on Figure 2.

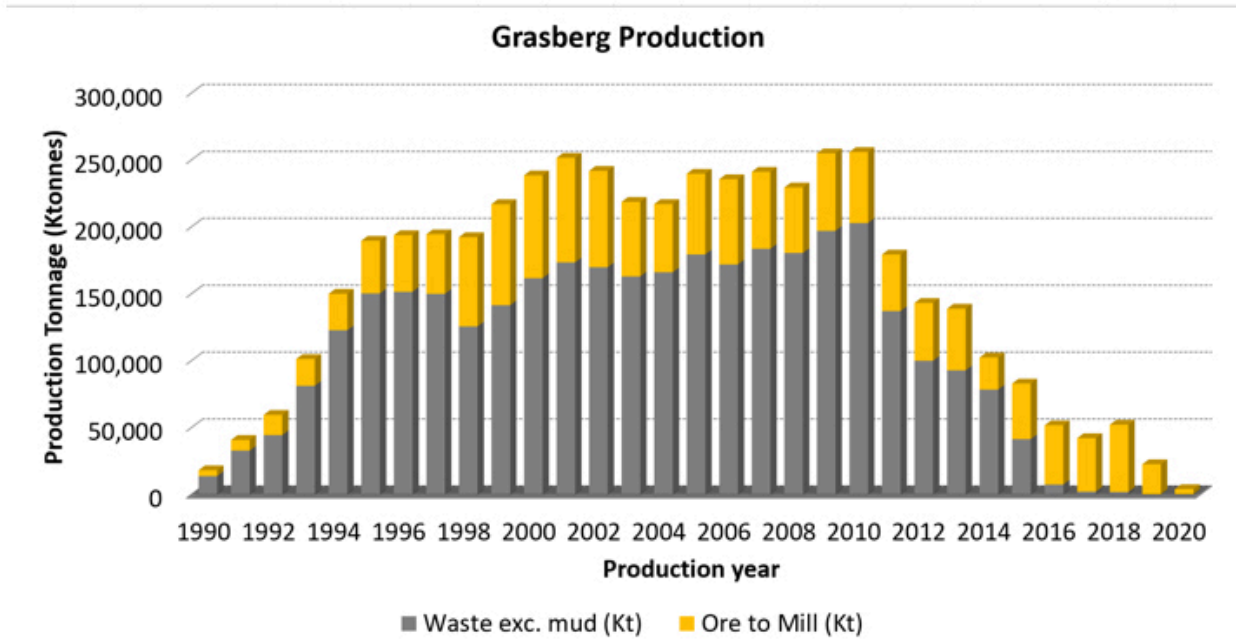

Figure 2 Total production of Grasberg open pit mine from 1990 to 2019

The slope optimization program at the Grasberg pit was directed at safely adding value by bringing metal forward from future block caving operation. The program evaluated increasing the inter-ramp slope and bench face angle for several benches before closing the pit by selecting the potential area, developing the new procedure/technique and monitoring/evaluating the progress. The program would not be started any higher up in the pit for several reasons:

- The Grasberg block cave is being developed and is in the process of ramping up production.

- The increase in the amount of material for both ore and overburden. 
- Lack of adequate space to put more overburden. The hauling cost will increase significantly as the pit gets deeper and the stockpiles get higher.

- Limited time/contract of work for maximizing deposits.

The extreme topography played an important role in optimizing the pit/block cave designs. The development of underground started 15 years ago and draw bell blasting started in December 2018. Therefore, the additional material from slope optimization had to take into consideration the block cave schedule.

\section{$2 \quad$ Slope optimization final results}

The slope optimization results are a comparison between metal forecasts made in first quarter 2017 (17Q1R5) and first quarter 2019 (19Q1R1). In the 17Q1R5 forecast, it was expected that the first ore gain would be in May 2017 as designated in Slope Optimization Task Force (SOTF) (Widijanto et al. 2018). The Optimization Program started with the following improvements:

a) Improve Titon rig for higher precision drilling,

b) Equipped Titon drilling operator with handheld tiltmeter,

c) Retrain and certification of drill operators,

d) Additional manpower for surveying and geotechnical, and

e) Technical training from Corporate Office for survey and geotechnical team as a QA/QC team.

It took until December 2017 before the Mine Plan Team started to see ore gains based on the final wall shape at elevation 3,280L. The final pit bottom bench was 3,055L, which was lower than the previous plan of 3,085L.

\subsection{Slope design optimization}

The slope design had evolved in 2018 based on obtained mining results. The initial plan for optimization in 2017 was to gradually increase the ISA from 54 degrees to 60 degrees at elevation PB9S5-3250L (radial section 270 to 360) and to resort back to the previous ISA at elevation 3,115L (Widijanto et al. 2018).

As the project was underway, more detailed geological data was collected (i.e. structure, seepage, drainage control and dewatering) and final wall trimming was improved using smaller equipment. Thereafter, the mine design incorporated further improvement by adding the radial section 200 to 270 and deepening the pit bottom to 3,055L. The December 2018 final design and results are shown in Figures 3 to 6.

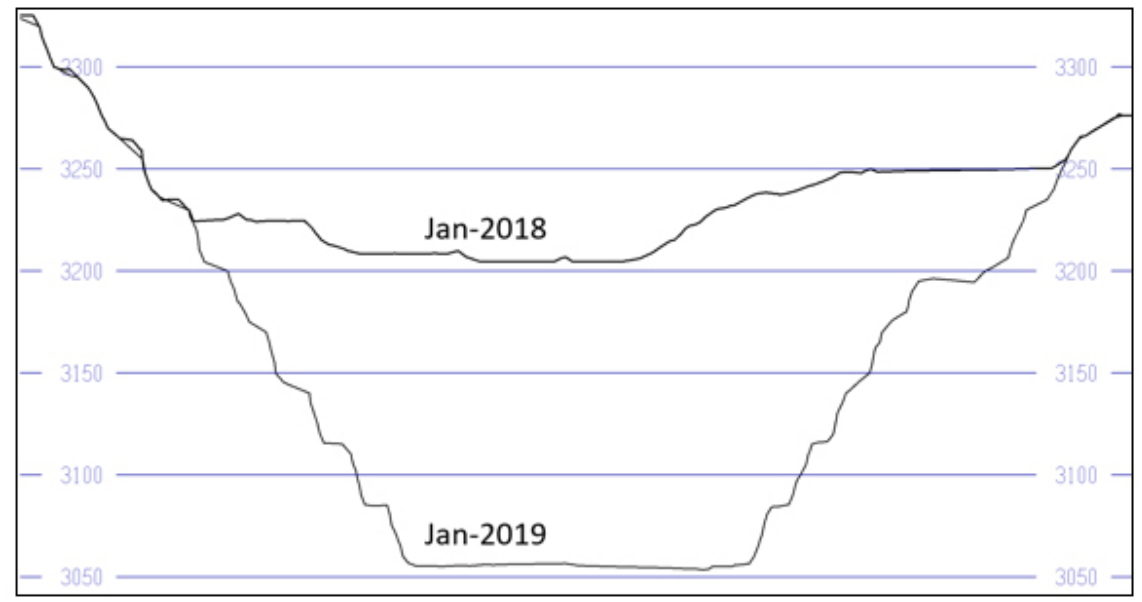

Figure 3 Cross section Jan. 1, 2018 and Jan. 1, 2019 


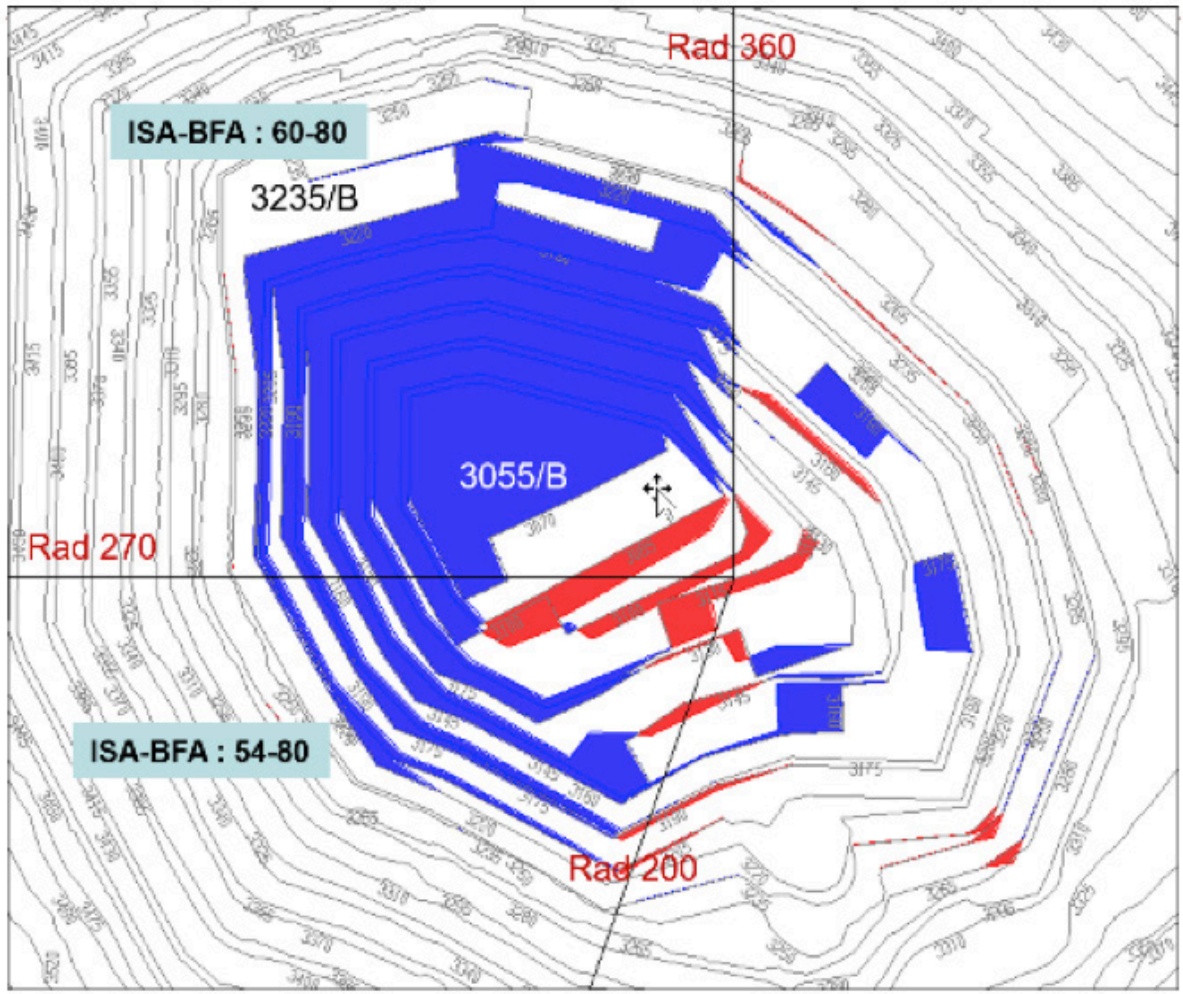

Figure 4 Plane view of slope optimization area with additional tonnage in blue and less tonnage in red

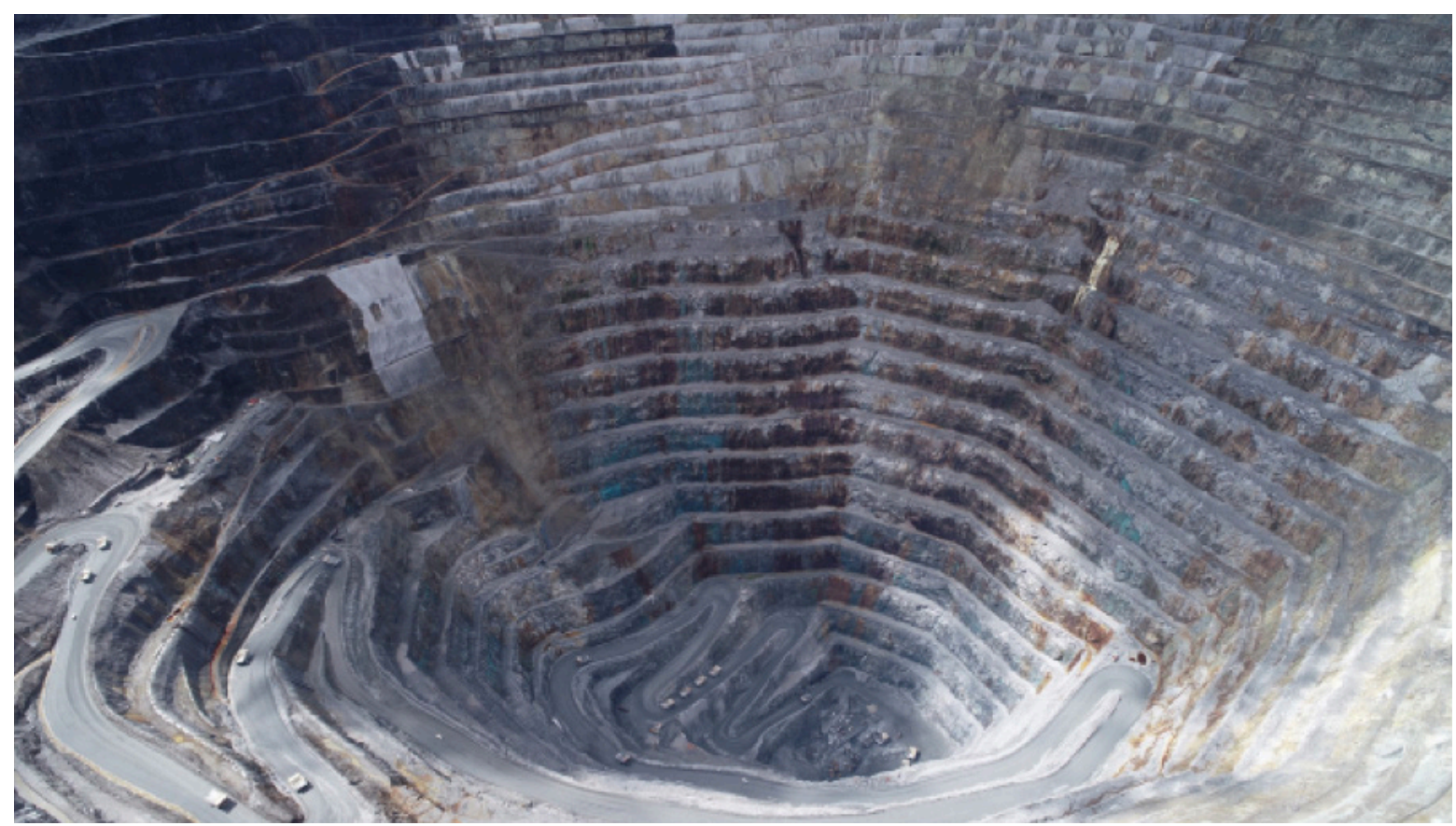

Figure 5 The aerial view of the slope optimization area 


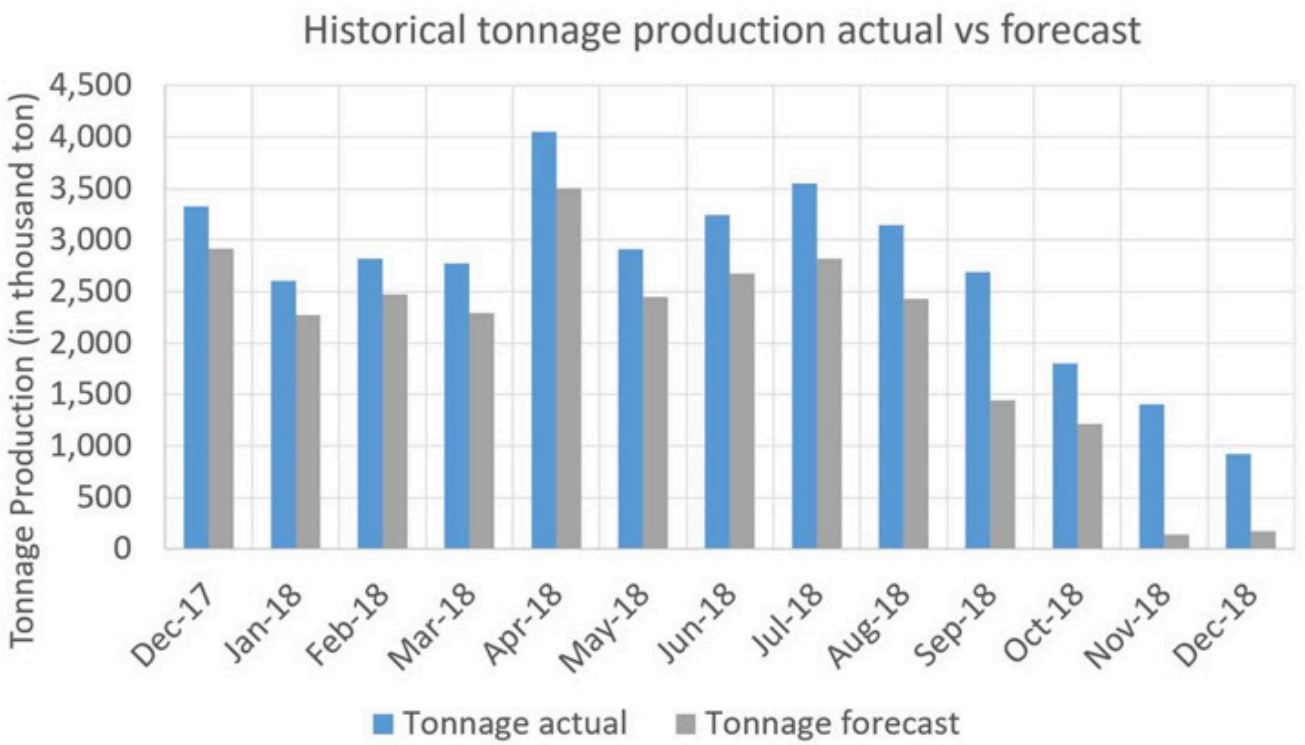

Figure 6 Ore tonnage gain

\section{$2.2 \quad$ Drilling and blasting}

During slope optimization, the pattern for production (blast hole) and pre-split drilling were changed. On average, the production (blast hole) pattern became $5 \mathrm{~m} \times 5 \mathrm{~m}$ or $6 \mathrm{~m} \times 6 \mathrm{~m}$ with a charge in the first row using $2 \times 200-250 \mathrm{~kg}$ (double decks) and gradually increasing the charge on the fourth row to 650 $\mathrm{kg}$, from the previous $6 \mathrm{~m} \times 7 \mathrm{~m}$ and $6 \mathrm{~m} \times 6 \mathrm{~m}$ with average charge per holes up to $700 \mathrm{~kg}$. The presplit pattern also was modified to be $0.75-1.25 \mathrm{~m}$ from previous $1.5-2.0 \mathrm{~m}$ spacing. In the wet ground, the pre-split holes were protected by sleeving with 2-inch PVC pipe, as showing in the Figure 7. The pad quality also was improved by maximum $\pm 1 \mathrm{~m}$ of undulation because of these changes.

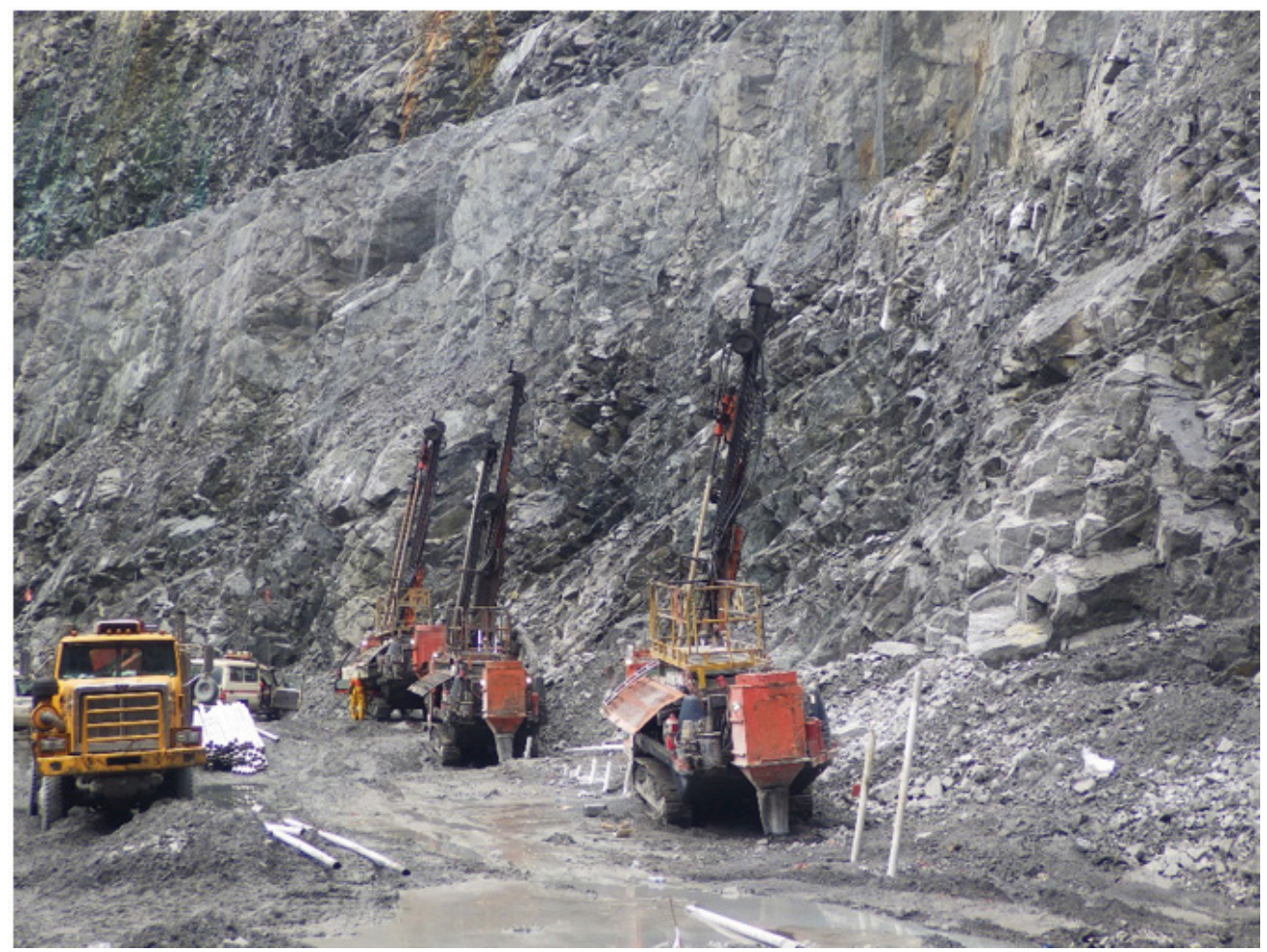

Figure 7 Two-inch PVC pipe is used to prevent collapsed holes in the saturated ground. The crest is protected by wire mesh to reduce rock bouncing to the drilling work area 
The total length of Blashole and Pre-split drilling had increased by 10 percent and 100 percent, respectively, as shown in Figure 8 and 9. As compared to 2017, the rate of drilling hole per total tonnage ore for Blasthole Drilling in 2018 has increased by 40 tons/hole. The total pit perimeter in 2018 also increased by $2,400 \mathrm{~m}$ and followed by increasing total pre-split drilling of 100,000 m more. Based on that data, the average spacing of pre-split decreased from $1.1 \mathrm{~m}$ to $1.0 \mathrm{~m}$.

Blasthole meterage actual vs forecast

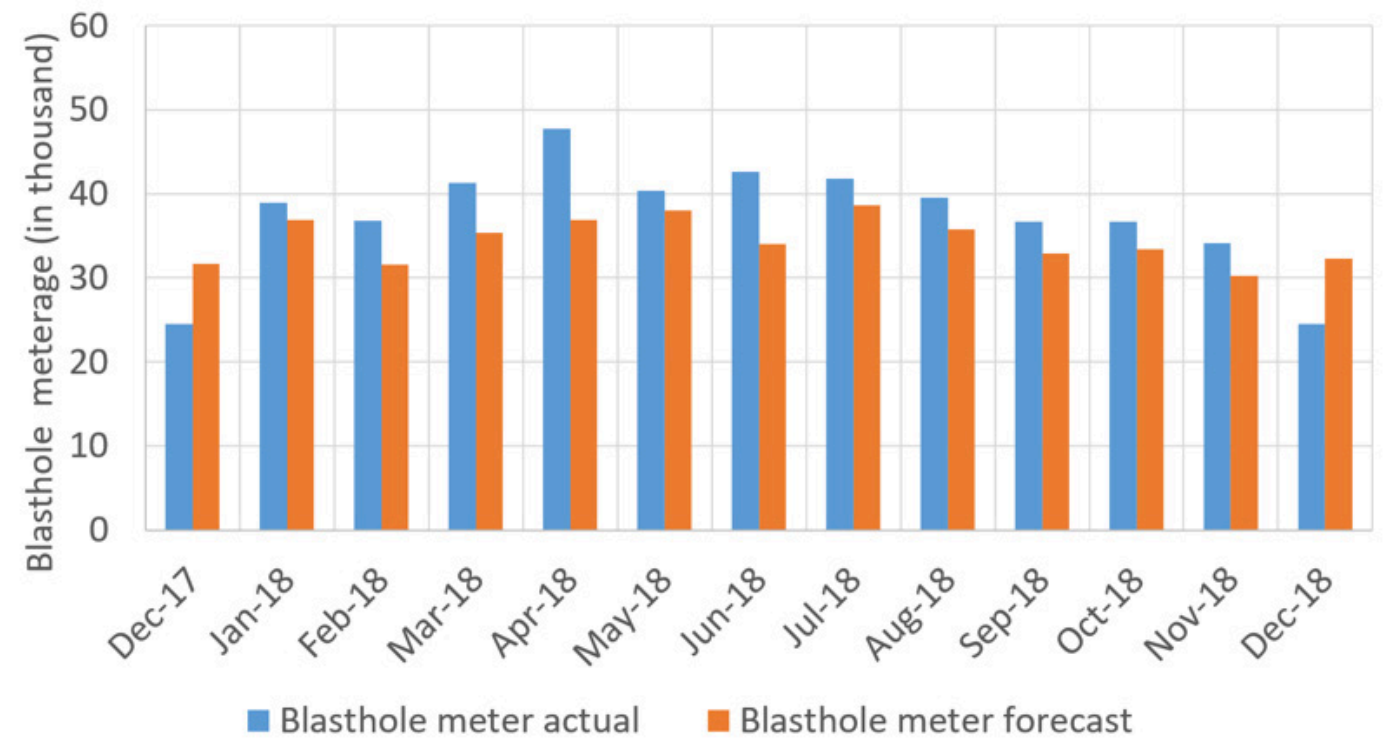

\section{Figure 8 Blasthole drilling meterage}

\section{Total meter pre-split actual vs forecast}

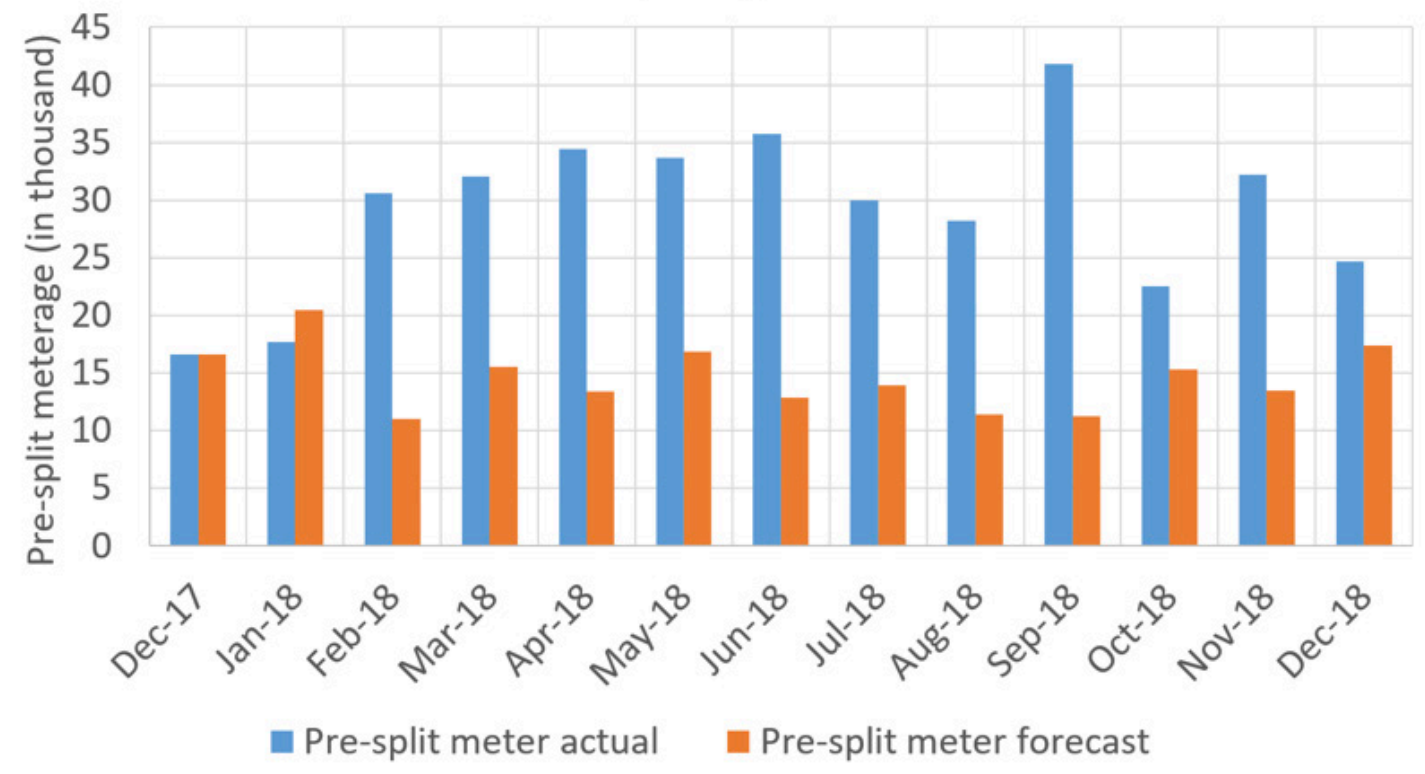

Figure 9 Pre-split drilling meterage 


\subsection{Slope audit process}

The surveyor takes some points using certain density that is required for slope audit after the shovel completing the digging. The slope audit provided information to determine whether or not the mining achieved the final wall design and to ensure all of the broken muck was removed so the free-face would be open for the next production drilling area. There should be two free-faces opened by the shovel to dissipate blasting energy and reduce damage to the final wall. The $3 \mathrm{~m}$-material offset from the final slope was mined with excavator-type equipment due to its precise trimming to the half-barrel of the presplit.

The survey process takes as-built design using a point-cloud scanner, and the geotech team assessed the result every $50 \mathrm{~m}$ length of mining. A detailed review of the crest and toe condition determined whether the results were acceptable or required more trim work. If the combination between hard toe and crest lost resulted in less Catch Bench Width (CBW) than the design, then the required slope stability/cover project was used to mitigate the rock fall issue. The process of the slope audit can be seen in Figure 10 until Figure 12.

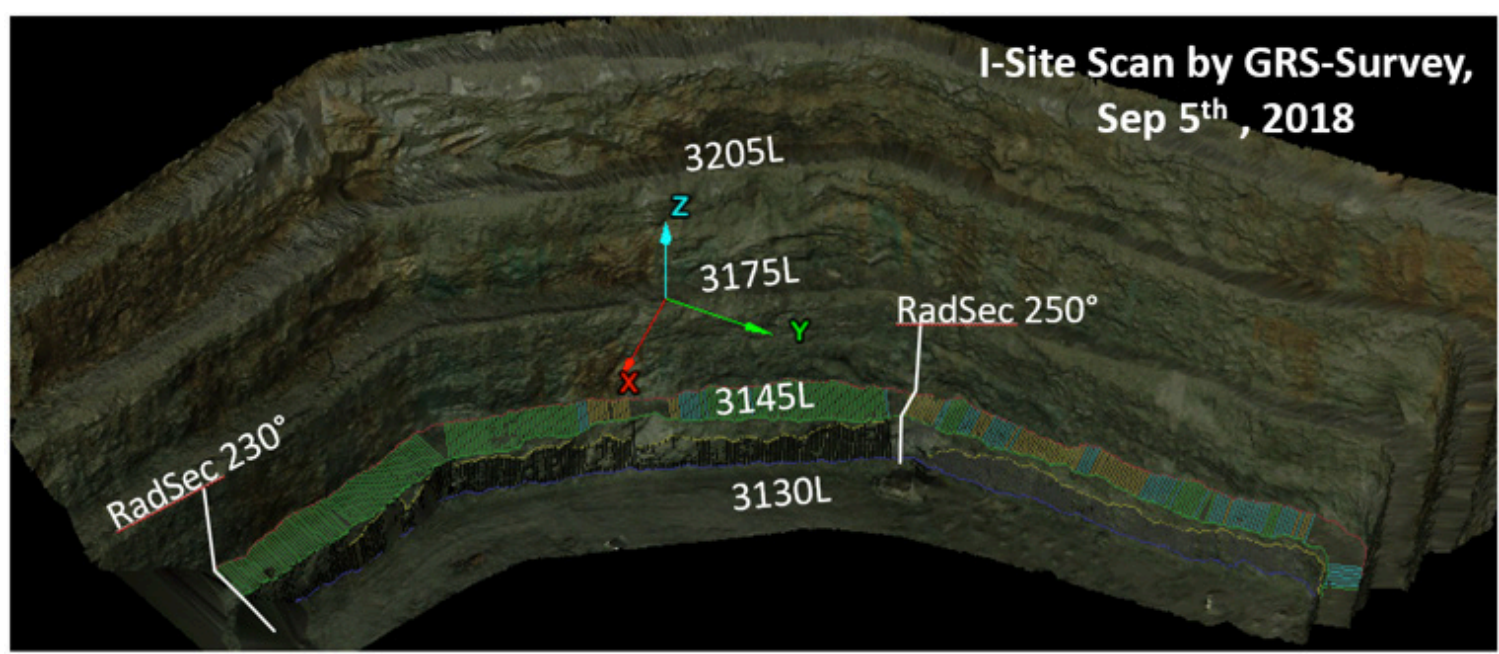

Figure 10 High resolution survey scan for slope audit process

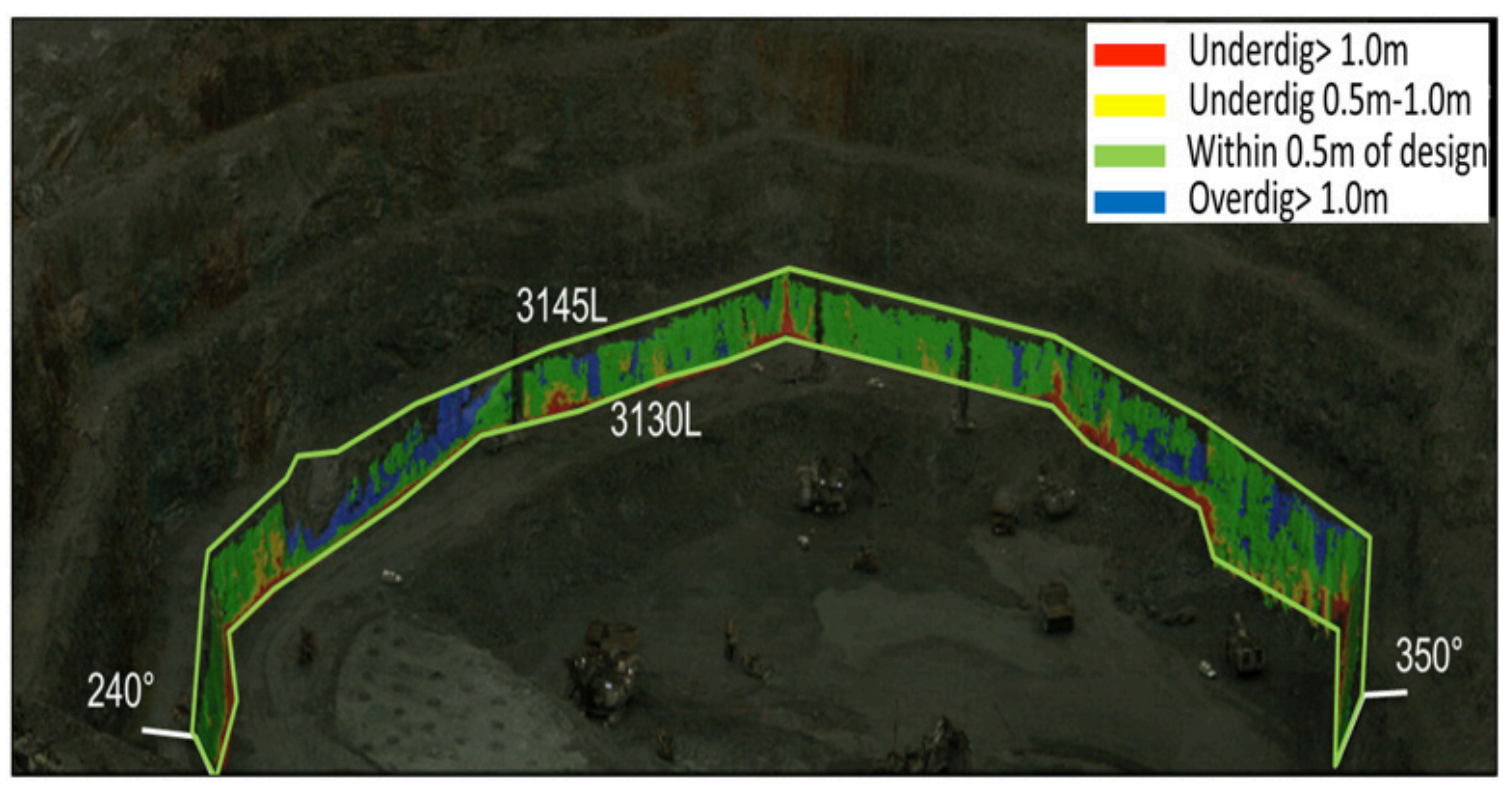

Figure 11 Slope trimming thickness 

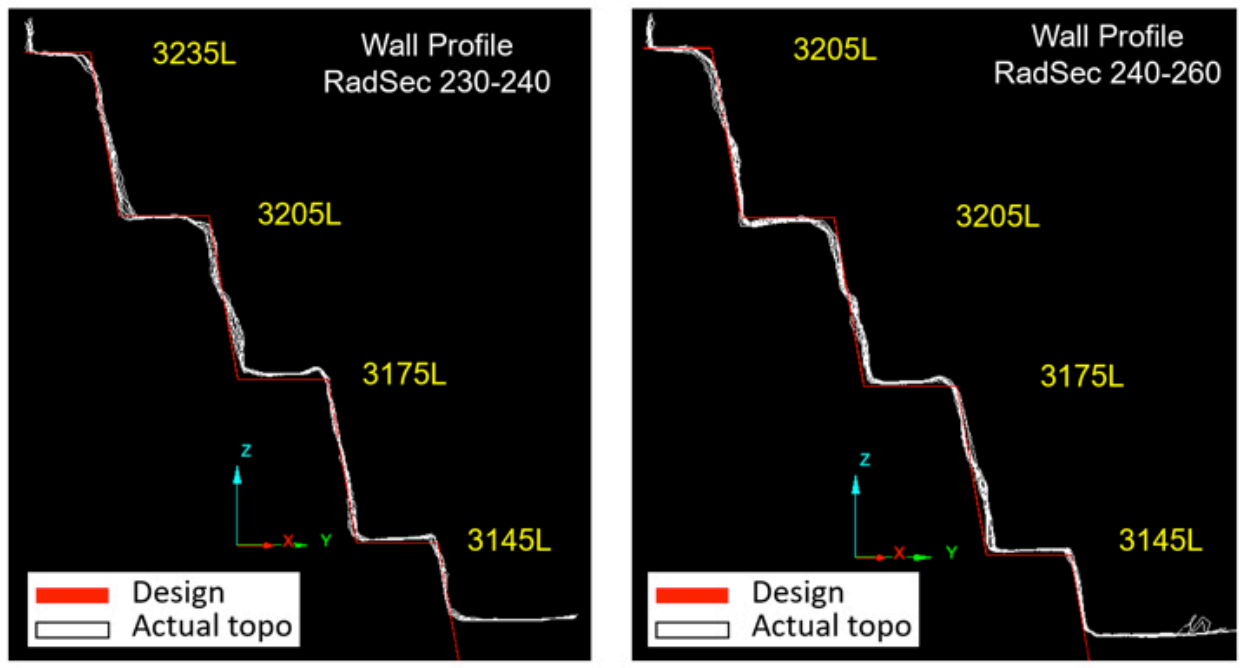

Figure 12 Wall profile on the slope audit at radial section (radsec) $230-240$ (left) and $240-260$ (right)

\subsection{Slope achievement}

Slope wall quality was determined after the shovel had completed mining the blasted muck before reaching the final wall. The purpose was to provide a free-face for the final wall blasting and to determine slope quality and any required slope protection. The quality of slope had been determined based on criteria of catch bench width and bench face angle achieved and based on Bench Face Achievement following to Read \& Stacey method (2009).

The final wall achievement at the end of slope stability program can be seen in the Figure 13 and 14 . If the bench width is less than criteria of $10.6 \mathrm{~m}$ than the area is subjected for slope stabilization/slope cover project.

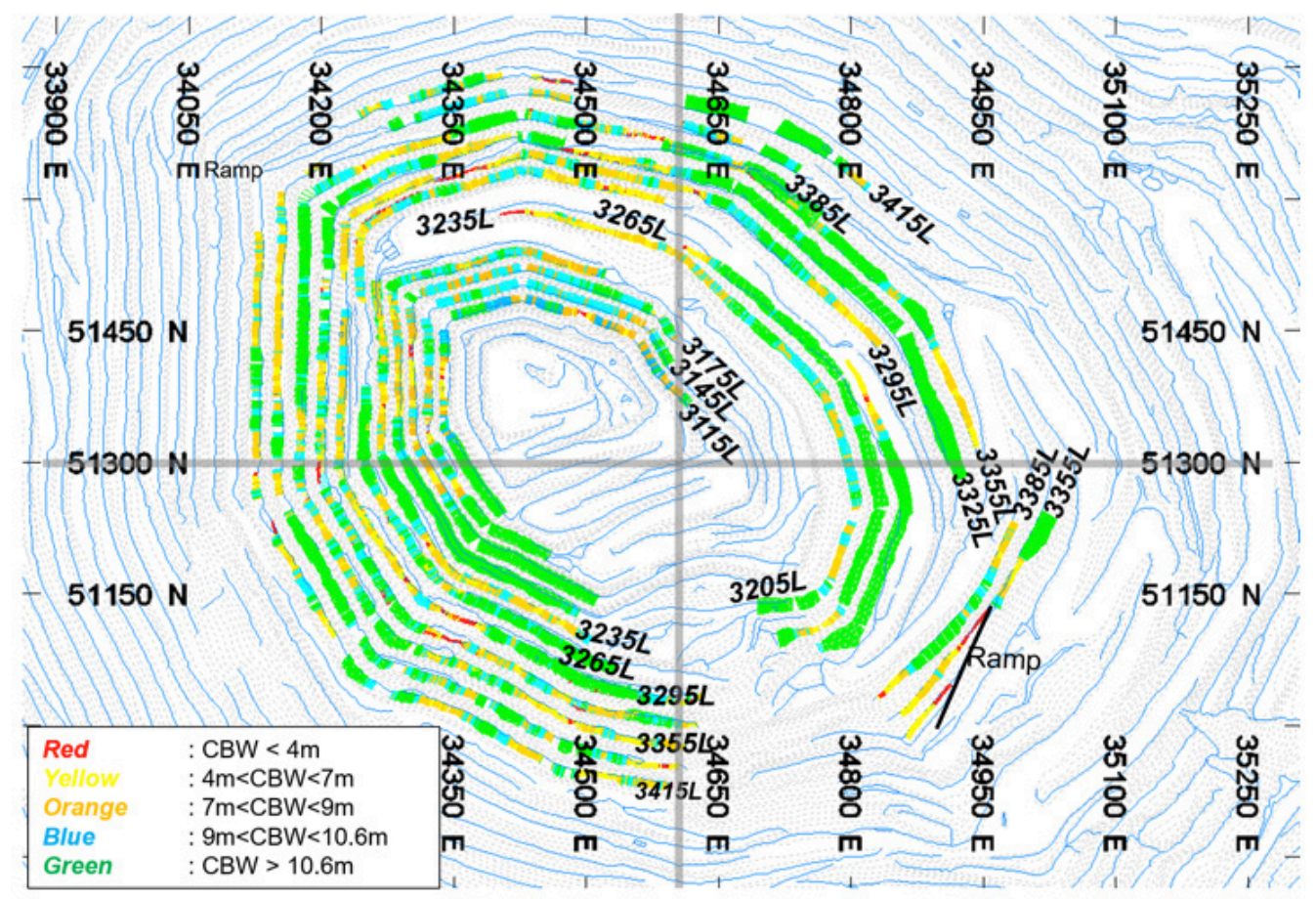

Figure 13 Bench width achievement to elevation 3055L 


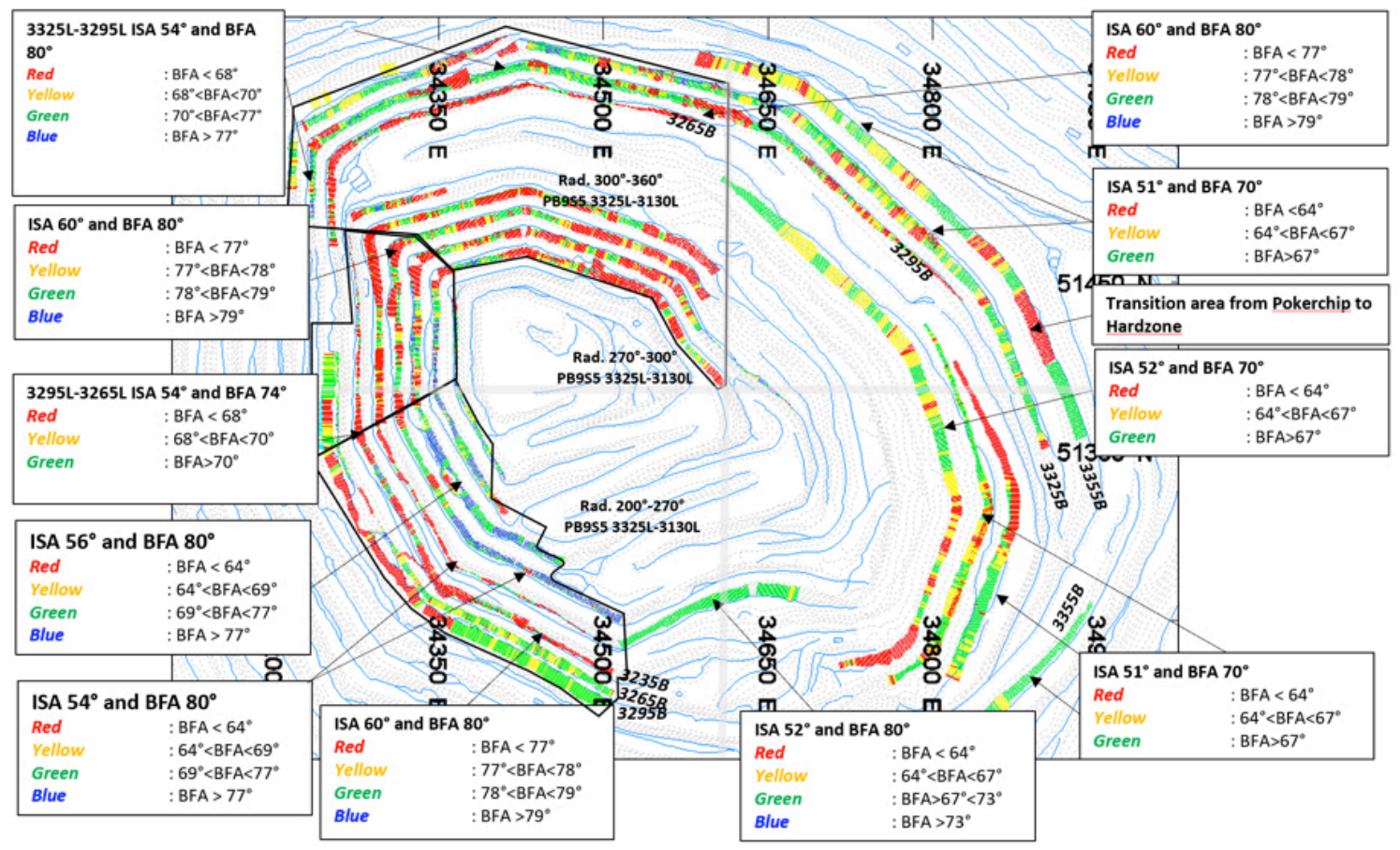

Figure 14 Catch bench achievement to elevation 3055L

\subsection{Slope stabilization/slope cover}

Steel mesh or geotextile was installed on the rock slope to contain small rock falls and ravelling from the crest and to preventing and dislodged rocks from bouncing. Steel mesh was anchored using rock bolt on the catch bench while the geotextile is anchored using concrete block. At the bottom, both steel mesh or geotextile is unpinned to allow rock fall release from the toe of the slope instead of accumulating behind the mesh or geotextile as shown in the Figure 15.

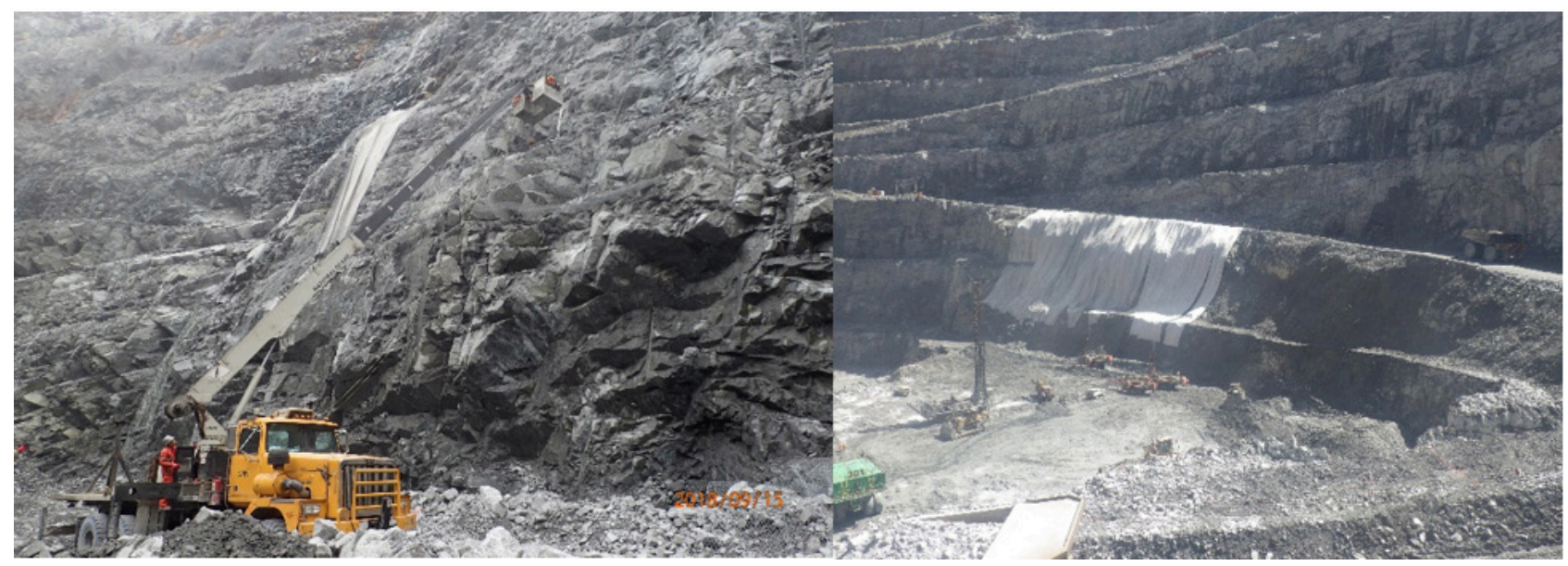

Figure 15 Installation of steel mesh, or geotextile

The decision to install steel mesh, or geotextile, was made in 2016 with the Final Wall Stabilisation project, which has aimed to reduce risks to hauling operations. In 2018, this project was combined with another project to protect the wall from a small rock event that could have bounced down several benches, especially where the CBW is less than $10.8 \mathrm{~m}$. Table 1 shows the perimeter of optimized slope against the slope cover project. The entire wall is not covered by steel mesh or geotextile because some area has high risk to install it. For example, the access is no longer available or the bench width is less than $3 \mathrm{~m}$ wide. At this case, geotechnical risk control is applied to control the risk, such as limitation to access $15 \mathrm{~m}$ from actual toe, us remote dozer within that area and increase catch bench width as rock fall simulation result. The area that cannot be mitigated with steel mesh and applied geotechnical risk control is shown in Figure 16. 
Table 1 Perimeter of pit and of slope stability project

\begin{tabular}{|c|c|c|c|}
\hline Elevation $(\mathbf{m})$ & Slope optimization perimeter $(\mathbf{m})$ & \multicolumn{2}{|c|}{ Slope cover } \\
\cline { 3 - 4 } & & Perimeter $(\mathbf{m})$ & Area $\left(\mathbf{m}^{\mathbf{2}}\right)$ \\
\hline 3205 & 588 & 150 & 2,250 \\
\hline 3175 & 740 & 250 & 3,750 \\
\hline 3145 & 686 & 69 & 1,035 \\
\hline 3115 & 622 & 345 & 5,175 \\
\hline 3085 & 530 & 300 & 4,500 \\
\hline 3055 & 445 & 10 & 150 \\
\hline
\end{tabular}

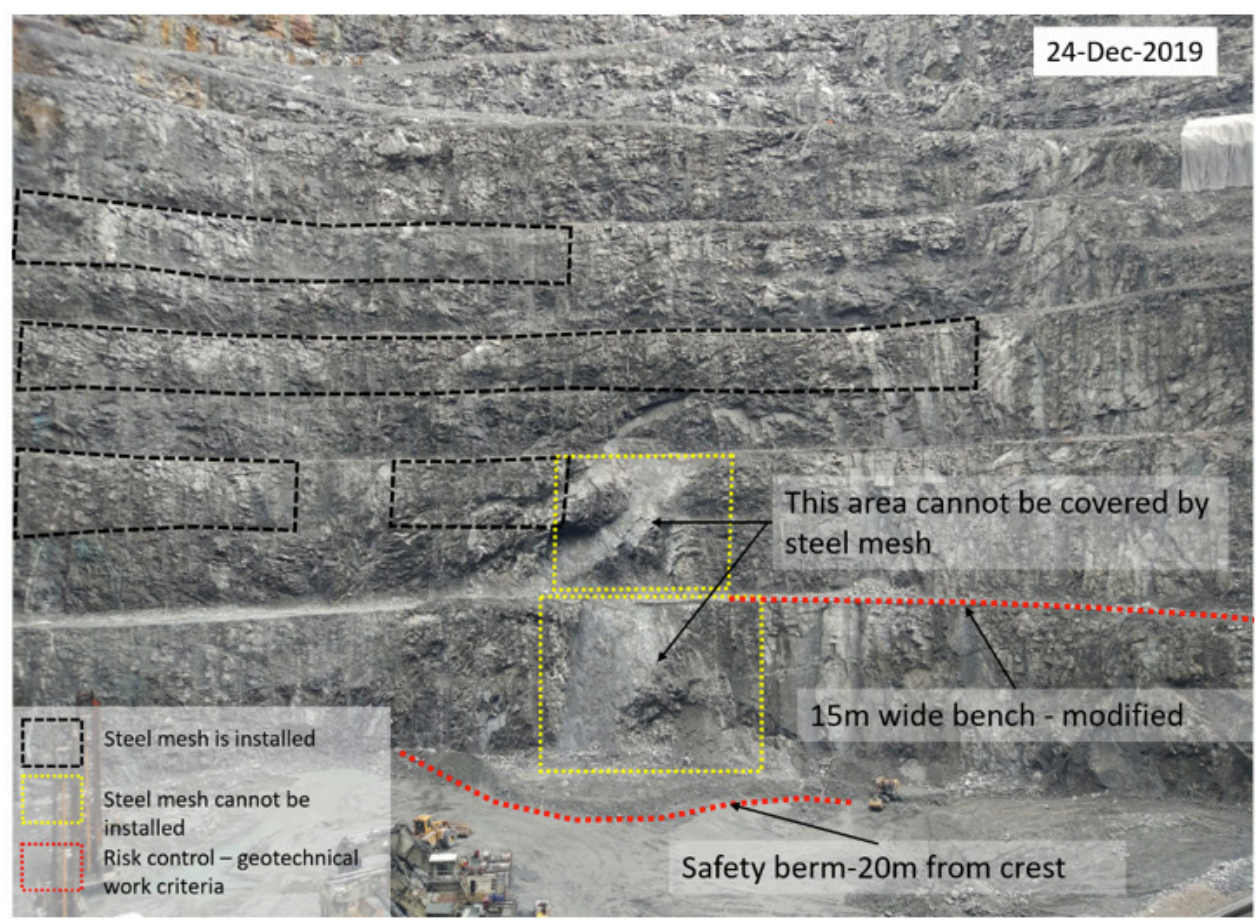

Figure 16 Safety concerns that prohibited installation of wire mesh and applied geotechnical risk control

\section{Conclusions}

The slope optimization program is part of the mining plan to maximize pit value by getting extra ore from the selected pit sectors 200 - 360 degrees. The inter-ramp slope angle of the wall on that sector had been succeeded to be steepened from 51 degrees to be 60 degrees. It added 8.4 million tonnes of high grade ore for open pit with metal payable 255 million lbs of copper and 660 kilo ozs of gold. The pit wall quality is excellence and the bottom pit is 2 benches deeper. This project required an intensive and detailed preparation phase, including equipment recondition, additional manpower, reskilling/retraining the operators, and technical skills improvement.

From an operational point of view, drilling-blasting improvement, controlled excavation, slope remediation and slope audit process are critical factors to ensure the quality of final slopes and the ultimate goal to maximize pit value safely.

The pit steepening is a high-risk effort, but it has high return. Therefore, this program should be done at the last before closing the pit. 


\section{Acknowledgement}

The author would like to thank the leadership of PT Freeport Indonesia and Freeport-McMoRan Inc. for permission to publish this paper. The contributions of personnel from Grasberg Mine Operations, the Long Range Planning Department and the Surface Mine GeoEngineering Department gratefully are appreciated.

\section{References}

Gautama, R \& Yuniar, A 2017, 'History of Grasberg mine design optimization', in the 4th Drill and Blast Summit 2017, Jakarta.

Nicholas, D 2002, 'Comment on PTFI Memo, dated 28 May 2002: Geotechnical assessments on steepening slope for mining PB5N (3625/L to 3503/L', Call\&Nicholas Inc report for PT Freeport Indonesia, Papua.

Read, J, \& Stacey, P 2009, 'Guidelines for open pit slope design', CSIRO, Canberra, pp. 265 - 326.

Schmelter, S \& Nicholas, D 2004, 'Analysis and documentation of the 9 October 2003 Grasberg south wall slide', Call\&Nicholas Inc report for PT Freeport Indonesia, Papua.

Widijanto, E, Gautama, R, Siburian, P, Sirait, J, \& Yuniar, A 2018, 'Slope optimization program to maximize pit value Grasberg Surface Mine, Papua - Indonesia ', in ISRM International Symposium: proceedings of 10th Asian Rock Mechanics Symposium, Singapore pp. 1-9. 